\title{
都市公園に対するライフサイクル $\mathrm{CO}_{2}$ 評価に関する研究
}

\author{
A Study of Life Cycle $\mathrm{CO}_{2}$ Evaluation to Urban Parks
}

\author{
市村 恒士* 奥 優一** \\ Koji ICHIMURA and Yuichi OKU
}

\begin{abstract}
To arrest global warming, it is also expected that the effect of carbon storage and sequestration of urban green spaces will be an important factor. On the other hand, the life cycle $\mathrm{CO}_{2}$ (hereafter, $\mathrm{LCCO}_{2}$ ) evaluation to reduce $\mathrm{CO}_{2}$ emissions is watched with interest by each sector. Because of this situation, the purpose of this study was to discuss the method of $\mathrm{LCCO}_{2}$ evaluation to urban parks, to apply that method to an actual urban park. The study parks estimated in this study was selected neighborhood park in Sapporo City, Hokkaido. The results are follows: 1) The method of $\mathrm{LCCO}_{2}$ evaluation to urban parks could be constructed, and it was possible to apply the constructed method to the study park. 2) In the study park under the present conditions, the amount of $\mathrm{LCCO}_{2}$ was estimated about 66.5t-C. 3) In the study park changed basing on a landscape planning considered to reduce the amount of $\mathrm{LCCO}_{2}$, the amount of $\mathrm{LCCO}_{2}$ was estimated about 46.1t-C. 4) Therefore, we grasped that it important for landscape planning to discuss reducing the amount of $\mathrm{LCCO}_{2}$.
\end{abstract}

Keywords: arrest global warming, life cycle $\mathrm{CO}_{2}$ evaluation, urban parks, urban landscape planting キーワード : 地球温暖化防止, ライフサイクル $\mathrm{CO}_{2}$ 評価, 都市公園, 都市緑化

\section{1.はじめに}

近年，地球温暖化問題が深刻化しており，その主な原因とされ る温室効果ガス, 特に二酸化炭素 (以下, $\mathrm{CO}_{2}$ ) の削減が社会全 体に対して求められている。

このような状況のもと, 気候変動枠組条約締約国会議 (COP) 等の国際的な議論の中では, 温室効果ガスの吸収源対策として 「都市緑化」が位置づけられることとなった ${ }^{1) な と 。 ~}$

これまで, 京都議定書にて位置づけられた $\mathrm{CO}_{2}$ の「吸収源」 としての都市緑地 ${ }^{2)}$ に対し, いかにその吸収固定量を評価すべき であるかという背景から, 都市緑地の $\mathrm{CO}_{2}$ 吸収・固定量に関す る妥当な推定法や推定の際に必要となる原単位等を明らかにすべ く面的な広がりのもつ都市や地域及び各種都市緑地等の $\mathrm{CO}_{2}$ 吸 収・固定に関する研究蓄積が進められてきた ${ }^{3) \sim 7) な ゙ 。 ~}$

他方で, $\mathrm{CO}_{2}$ の排出削減に向けた取り組みの 1 つとしてライ フサイクル $\mathrm{CO}_{2}$ (以下, $\mathrm{LCCO}_{2}$ ) 評価の重要性が認識されてい $3^{8)}$ 。 $\mathrm{LCCO}_{2}$ 評価は, 製品や構造物について, その資源採取か ら廃棄・再利用までの全過程（ライフサイクル）において排出さ れる全 $\mathrm{CO}_{2}$ 量を取り上げ評価する考え方である。

都市緑地においても, $\mathrm{LCCO}_{2}$ の視点に立つと, 特にレクリエー ション等の役割を期待した都市公園等では, 野球場等の新規整備 や草刈等の維持管理等における工事・作業等を原因とした $\mathrm{CO}_{2}$ の「排出」の側面があると考えられるが，これまでの研究では， それについてはあまり考慮されず, 都市緑地のライフサイクル全 体としては一部となる $\mathrm{CO}_{2}$ の「吸収源」としての側面のみが着 目されている状況にあったといえる。

既に建築や各種の製造業界等では，建築物等に対する $\mathrm{LCCO}_{2}$ に関する多くの研究が進められ ${ }^{91,10) な と, ~} \mathrm{LCCO}_{2}$ 評価に基づいた建 築物等の設計・運用による $\mathrm{CO}_{2}$ の排出量削減に成功している。

特に建築分野においては, 従来から莫大な $\mathrm{CO}_{2}$ を排出してき たが, 近年では, 建築物に対する環境評価の必要性のもと, CASBEE の検討, 導入等が行われる流れの中, $\mathrm{LCCO}_{2}$ 評価につ
いても主に建築物の計画・設計段階に導入され, 各ライフサイク ル過程における $\mathrm{CO}_{2}$ 排出量の評価結果を考慮しながら建築物の 再計画・再設計等を実施し, 定性的でなく定量的に $\mathrm{CO}_{2}$ の排出 削減に取り組んでいる。

これらの取り組みにより，建築分野においては，直接的な $\mathrm{CO}_{2}$ の排出削減という効果のみならず，近年の顧客の環境意識に対応 した環境を配慮した製品としての建築自体の価値向上や，環境配 慮による企業のイメージアップ等の間接的な効果も発揮している。

一方で, 都市緑地における $\mathrm{LCCO}_{2}$ 評価に関する研究は, 必要 性が指摘 ${ }^{8}$ されているものの, 具体的な評価手法の検討や実際の 都市緑地に対する評価手法の適用等については, 殆ど手つかずの 状況といえる。

このような背景のもと, 本研究は, 代表的な都市緑地である都 市公園に対する $\mathrm{LCCO}_{2}$ の評価手法を検討・構築すること，その 構築した $\mathrm{LCCO}_{2}$ 評価手法を実際に存在する都市公園（以下，評 価対象公園）や $\mathrm{CO}_{2}$ の削減シナリオに基づいた公園整備計画に 対して適用し，都市公園に対する $\mathrm{LCCO}_{2}$ 評価を試行すること， それらに基づき都市公園等の都市緑地における $\mathrm{LCCO}_{2}$ 評価の可 能性等を検討することを目的とした，「都市緑地に対する $\mathrm{LCCO}_{2}$ 評価」に関する萌芽的研究である。

\section{2. 研究の方法}

（1）都市公園に対する $\mathrm{LCCO}_{2}$ 評価手法の検討

(i ) 基本的な考え方

本研究で構築した都市公園に対する $\mathrm{LCCO}_{2}$ 評価手法は, 基本 的に比較的類似点の多いと思われる建築の $\mathrm{LCCO}_{2}$ 評価手法を参 考9), 11) なととした。

一方, 特に本研究に扔いて, 都市公園に対する $\mathrm{LCCO}_{2}$ 評価手 法の検討を行うに当たり, 以下のような 2 つの留意点が存在した。

1 つ目として, 公園の計画・設計段階における整備費用の「積 算」と連携した $\mathrm{LCCO}_{2}$ 評価手法とすることである。 
これは，基本的に殆どの都市公園整備の際になされる「積算」 と連携した形で行うことが可能な $\mathrm{LCCO}_{2}$ 評価手法の構築を視野 に入れることで, 汎用性や都市緑地計画への応用等が期待出来る と考えられたためである。

2 つ目として, 評価対象公園（後述するとおり北海道札幌市の 都市公園）に関して得られる情報（積算等に関する情報等）等を 同時並行的に調査, 収集し, その情報に対応可能な $\mathrm{LCCO}_{2}$ 評価 手法とすることである。

これは, 本研究では, 実際に存在する評価対象公園に対して $\mathrm{LCCO}_{2}$ 評価を適用することを目的の 1 つとしているためである。

本研究で構築した $\mathrm{LCCO}_{2}$ 評価手法の考え方の詳細について以 下に示す。

（ii）ライフサイクル過程の設定

都市公園のライフサイクルの過程は, 公園緑地工事大系ツリ - ${ }^{12)}$ 等を参考に「資材生産過程」「資材輸送過程」「基盤整備工 事過程」,「植栽工事過程」,「施設整備工事過程」,「グラウンド・ コート整備工事過程」, 及び「運用・維持管理過程」の 7 過程に 区分した。

（iii）原単位項目の設定

各原単位項目の設定においては, 基本的に建築分野の $\mathrm{LCCO}_{2}$ 評価における原単位項目に準じた。

ただし, 現場での工事過程（：基盤整備工事過程, 植栽工事過 程, 施設整備工事過程, 及びグラウンド・コート整備工事過程) に関する原単位については, 整備費用の「積算」の際に用いる項 目を原単位項目とした。

これは, 建築分野ではエネルギー関連統計等を用いて, 構造や ビルディングタイプごとに一般化された床面積や施工費用あたり の原単位を設定している事例 ${ }^{9), 13 \sim 15)}$ が多いが，都市公園に関し ては様々な整備がなされ工事の一般化が困難であることや, 前述 した通り「積算」と連携した $\mathrm{LCCO}_{2}$ 評価手法を構築することを 視野に入れたためである。

(iv) $\mathrm{LCCO}_{2}$ 評価の対象期間の設定

$\mathrm{LCCO}_{2}$ 評価の対象期間については, 都市公園は建築物等とは 異なり，廃棄という過程が存在しないものといえることから，資材 生産から再整備等が行われるまでとすることが望ましいと考えられる。

本研究では, 評価対象公園の存在する札棍市の住区基幹公園の 開設後年数や再整備の現状を鑑み, $\mathrm{LCCO}_{2}$ 評価の対象期間は,

便宜的に公園開設後 50 年までと設定した。

\section{（2）各原単位項目における原単位の収集・把握}

本研究に打ける都市公園の $\mathrm{LCCO}_{2}$ 評価に関する各原単位項目 の原単位の把握方法を以下に整理する。

なお, すべての原単位は, 炭素換算重量 (単位 : $\mathrm{kg}-\mathrm{C}, \mathrm{t}-\mathrm{C}$ 等 $)^{16)}$ で統一し把握した。

資材生産過程の原単位については, 文献調査 ${ }^{11)}$ で得られた原単 位を用いた。

資材輸送過程の原単位については, 文献調査 ${ }^{12)}$ から得た燃料消 費量と燃料の消費による $\mathrm{CO}_{2}$ 排出量 (軽油 $\left.: 0.7212 \mathrm{~kg}-\mathrm{C} / \ell\right)^{17}$ から算出した。

基盤整備工事過程, 植栽工事過程, 施設整備工事過程 ${ }^{18}$, グラ ウンド・コート整備工事過程, 及び運用・維持管理過程の公園草 㺫作業の原単位については, 主に評価対象公園の存在する札幌市 の公共工事積算システムから得た各工事にかかる施工時間及び作 業機械の消費燃料量と, 燃料の消費による $\mathrm{CO}_{2}$ 排出量（軽油 $0.7212 \mathrm{~kg}-\mathrm{C} / \ell$ ，ガソリン $0.6433 \mathrm{~kg}-\mathrm{C} / \ell$ l $)^{177}$ から算出した。

なお，これらの過程において，札幌市の公共工事積算システム のデー夕の不足部分については文献調查 ${ }^{11}$ から得たデータで補完 した。また，原単位項目となる作業に複数の機械が使用される場 合は, 各機械の $\mathrm{CO}_{2}$ 排出量の合計を原単位とした。
運用・維持管理過程の電力消費の原単位，及び樹木による $\mathrm{CO}_{2}$ 吸収固定量の原単位については, 評価対象公園の存在する北海道 を対象として, 北海道電力の報告から得た $\mathrm{CO}_{2}$ 排出実績値 ${ }^{19}$, 及 び北海道の都市公園における樹冠被覆面積当たりの年間 $\mathrm{CO}_{2}$ 固 定量に関する既往研究 ${ }^{3)}$ のデー夕を用いた。

\section{（3）評価対象公園に対する $\mathrm{LCCO}_{2}$ 評価の適用}

(i) 評価対象公園の選定

実際の都市公園への $\mathrm{LCCO}_{2}$ 評価を試みるにあたり, 本研究で は，これまでの構築してきた研究体制等を踏まえ各種の情報提供 が比較的容易に受けることが可能な札幌市の都市公園を対象に, 本研究で構築する $\mathrm{LCCO}_{2}$ 評価を実行するために必要な情報であ る新規整備時の積算資料や植栽関連資料等の収集が可能であった こと，ライフサイクル過程の多様性を考慮し多様な土地利用をも つこと, 萌芽的段階の評価対象として適度な規模等として考えら れる近隣, 地区公園であること等を条件に, 北海道札幌市の近隣 公園「屯田一番通公園」を評価対象公園として選定した。

（ii）評価対象公園（現状タイプ）に対する $\mathrm{LCCO}_{2}$ 評価の適用

これまで構築してきた $\mathrm{LCCO}_{2}$ 評価手法の実用性等を明らかに するため，まず，その評価手法を評価対象公園の現状の整備状況 （以下，現状タイプ）に対し適用した。

実際には，ここまで把握してきた各過程における各原単位項目 の原単位に, 評価対象公園の資材量, 作業量, 造成量, 及び維持 管理作業に関する量等を乗じて，各作業等の $\mathrm{CO}_{2}$ 排出・吸収量 を算出し，それらを積算し，各ライフサイクル過程，及び全ライ フサイクルの $\mathrm{CO}_{2}$ 排出・吸収量を算定することで $\mathrm{LCCO}_{2}$ 評価を 実行している。評価対象公園の新規整備に関わる資材量・作業量 等については，札幌市から提供された新規整備時に作成された造 成工事積算資料に記載された值を用い，維持管理に関わる草刈等 の作業量等は札幌市へのヒアリング調査から得た值を用いた。

（iii）評価対象公園（改善夕イプ）に対する $\mathrm{LCCO}_{2}$ 評価の適用 評価対象公園の現状の整備状沉 ( : 現状夕イプ) を踏まえ, 評 価対象公園の $\mathrm{LCCO}_{2}$ 削減を視野に入れた土地被覆, 土地利用や 維持管理等の計画を想定（以下，削減シナリオ）した。その想定 した削減シナリオに基づいた評価対象公園の整備状況（以下，改 善タイプ）に対しても本研究で構築した $\mathrm{LCCO}_{2}$ 評価を適用し, それにより改善シナリオの効果等について検証した。

\section{3. 結果及び考察}

\section{（1）都市公園に対する $\mathrm{LCCO}_{2}$ 評価に関する原単位}

都市公園に対する $\mathrm{LCCO}_{2}$ 評価に関する原単位を把握した結果, 表 1 に示すとおり, 本研究で設定した各ライフサイクル過程の各 原単位項目における $\mathrm{CO}_{2}$ の排出や吸収固定に関する原単位を網 羅的に抽出することが出来た。

これらの原単位は, 積算時に算出される各種の資材量・作業量 の項目之関連づけられており, 若干の不足は存在すると考えられ るが概ねの工事等に対応出来る原単位が把握されたと考えられる。

また，実際に各々の原単位をみても，用いる資材や作業等の工 事により大きな $\mathrm{CO}_{2}$ 排出の相違があることが把握された。

例えば，施設整備工事過程の園路広場工の舗装には様々な種別 があるが，各種別の $\mathrm{CO}_{2}$ 排出量の原単位をみると，「ダス卜舗装」 $4 \mathrm{~kg}-\mathrm{C} / 100 \mathrm{~m}^{2}$,「アスファルト埔装・車道・舗装幅 $3 \mathrm{~m}$ 以上」 30 $\mathrm{kg}-\mathrm{C} / 100 \mathrm{~m}^{2}$, 近年バイオマス資材の利用として注目されている 「木チップ舗装」 $6 \mathrm{~kg}-\mathrm{C} / 100 \mathrm{~m}^{2}$ となり大きな相違がみられた。

（2）評価対象公園（現状タイプ及び改善タイプ）の概要 評価対象公園である「屯田一番通公園」の現状タイプ及び改善 タイプの整備状況等について図ー 1 に示す。

評価対象公園は，平成 19 年に開設された近隣公園であり，公 園面積は，15,542 m²（公園台帳）となっている。 
（i ）現状タイプの整備状況

現状タイプの評価対象公園の土地被覆 ・土地利用及び維持管理 等の状況（図-1）を整理すると, 大型コンビネーション遊具や 健康遊具等の遊具（11 基）のある遊戯広場（ゴムチップ舗装 101 $\mathrm{m}^{2}$, ダスト舗装 $1,250 \mathrm{~m}^{2}$, レンガブロック舗装 $\left.216 \mathrm{~m}^{2}\right)$, 野球広場 （クレイ舗装 $1,700 \mathrm{~m}^{2}$, 芝 $\left.5,810 \mathrm{~m}^{2}\right)$, 流用土を用いた盛土 $\left(740 \mathrm{~m}^{3}\right.$ ) によるスキー山, 歩道 (アスファルト舗装 : $688 \mathrm{~m}^{2}$, アスファル トベンガラ舗装 $433 \mathrm{~m}^{2}$, 木チップ舗装 $170 \mathrm{~m}^{2}$ ), 車道（アスファル 卜舖装 $487 \mathrm{~m}^{2}$ )，樹木（新規高木植栽 27 本，樹冠被覆率 $20 \%$ (0.31ha)）及び照明灯（電力使用量実績值 $8,866 \mathrm{kwh} /$ 年 : 札幌 市ヒアリングより）等の整備がされていること, 野球広場の芝部
では「芝刈年 6 回集草なし」その他の芝部分では「芝刈年 3 回集 草あり」の維持管理活動がなされていること等が把握された。

(ii）改善タイプの整備状況

評価対象公園における「現状タイプ」を踏まえ設定した $5 つ の$ $\mathrm{CO}_{2}$ 削減シナリオ（1)〜 (5)）について以下に整理する。

新規整備時（主に土地被覆や土地利用）に関するシナリオは, (1)〜 (4)の 4 つ，維持管理時に関するシナリオは，1つ（5)のみ） を設定した。

(1)「歩道の木チップ舗装化」は，現状タイプにおいてアスファ ルト舗装だった歩道を木チップ舗装とするシナリオ，(2)残土の 公園内活用」は，現状タイプにおいて残土として処理していた発

表 -1 都市緑地に対する $\mathrm{LCCO}_{2}$ 評価に関する原単位

\begin{tabular}{|c|c|c|c|c|}
\hline \multicolumn{4}{|c|}{ 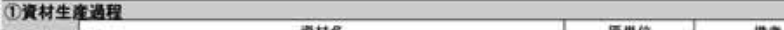 } & \\
\hline \multirow{33}{*}{ (1) } & 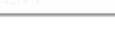 & 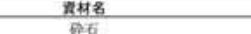 & \begin{tabular}{|l} 
原戰但 \\
\end{tabular} & $\frac{13}{2}$ \\
\hline & & 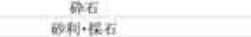 & $\begin{array}{l}0.003 \mathrm{~g}-\mathrm{Ckg} \\
0.003 \mathrm{~g}-\mathrm{Ckg}\end{array}$ & 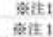 \\
\hline & & 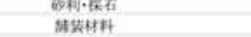 & $\begin{array}{l}0.003 \mathrm{~g}-\mathrm{Ckg} \\
0.037 \mathrm{~g}-\mathrm{Ckg}\end{array}$ & 安证 \\
\hline & & 生坛 & $0.056 \mathrm{~g} \cdot \mathrm{Ckg}$ & 曹往 1 \\
\hline & & sti & $0.067 \mathrm{~g}-\mathrm{Ckg}$ & 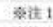 \\
\hline & & tx弪骨 & $0.093 \mathrm{~g}-\mathrm{Clkg}$ & 絭社 1 \\
\hline & & tex & $0.223 \mathrm{~g} \cdot \mathrm{Ckg}$ & 耕地 \\
\hline & & 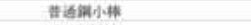 & $0.257 \mathrm{~g}-\mathrm{Ckg}$ & 䇣注 1 \\
\hline & & Dosent & $0.304 \mathrm{~g}-\mathrm{C} / \mathrm{kg}$ & 䄅数 1 \\
\hline & & 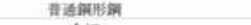 & $0.31 \mathrm{~g}-\mathrm{C} / \mathrm{kg}$ & 来注 1 \\
\hline & & 合板 & $0.347 \mathrm{E}-\mathrm{CKk}$ & 娄社 1 \\
\hline & & 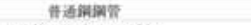 & $0.379 \mathrm{~g}-\mathrm{Ckg}$ & कas 1 \\
\hline & & 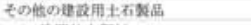 & $0.382 \mathrm{p} \cdot \mathrm{Ckg}$ & 宫社 1 \\
\hline & & 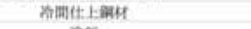 & $0.402 \mathrm{~g}-\mathrm{Ckg}$ & क्स 1 \\
\hline & & 象和 & $0.481 \mathrm{~g} \cdot \mathrm{Ckg}$ & 製社 1 \\
\hline & & 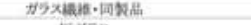 & $0.62 \mathrm{~g} \cdot \mathrm{Ckg}$ & \$i 1 \\
\hline & & Eथम5x & $0.62 \mathrm{q}-\mathrm{Ckg}$ & कi末 1 \\
\hline & & Toxfyr留・管・H & $0.64 \mathrm{~g}-\mathrm{Ckg}$ & 羅 1 \\
\hline & & 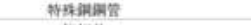 & $0.642 \mathrm{~g} \cdot \mathrm{Ckg}$ & क蚔 1 \\
\hline & & 19 & $0.646 \mathrm{~g}-\mathrm{C} / \mathrm{kg}$ & 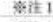 \\
\hline & & 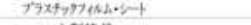 & $0.67 \mathrm{~g}-\mathrm{Ckg}$ & क洋 1 \\
\hline & & 楼然具 & $0.683 \mathrm{~g}-\mathrm{Ckg}$ & 社 1 \\
\hline & & ตectute) & $0.686 \mathrm{~g}-\mathrm{Ckg}$ & \%it 1 \\
\hline & & 知管 & $0.693 \mathrm{~g}-\mathrm{Ckg}$ & *证 1 \\
\hline & & 料是 & $0.781 \mathrm{~g}-\mathrm{CKk}_{\mathrm{g}}$ & Wit 1 \\
\hline & & 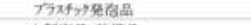 & $0.097 \mathrm{~g} \cdot \mathrm{Ckg}$ & कet 1 \\
\hline & & 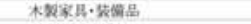 & $1.02 \mathrm{~g} \cdot \mathrm{Ckk}_{\mathrm{g}}$ & कal 1 \\
\hline & & 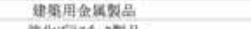 & $1.13 \mathrm{~g} \cdot \mathrm{Ckg}$ & \%i任 \\
\hline & & 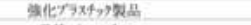 & $124 \mathrm{~g} \cdot \mathrm{CK}_{\mathrm{g}}$ & क数 1 \\
\hline & & 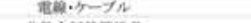 & $1.78 \mathrm{~g} \cdot \mathrm{Ckg}$ & 察往 1 \\
\hline & & 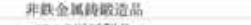 & $2.3 \mathrm{~g}-\mathrm{Ckg}$ & 慗社 1 \\
\hline & & 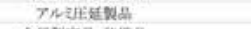 & $252 \mathrm{~g} . \mathrm{Ckg}$ & Wit 1 \\
\hline & & 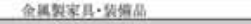 & $4.5 \mathrm{~B}-\mathrm{Ckg}$ & site 1 \\
\hline \multicolumn{5}{|c|}{ 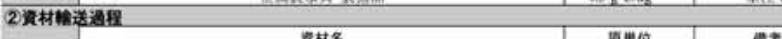 } \\
\hline & & 罢林名 & 原單位 & 留羊 \\
\hline & & 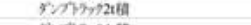 & $3.2 \mathrm{~kg}-\mathrm{Ch}$ & stil:2 \\
\hline & & 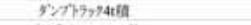 & $4.9 \mathrm{~kg}-\mathrm{Ch}$ & sat 2 \\
\hline & & 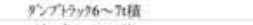 & $6 \mathrm{~kg}-\mathrm{Ch}$ & \%证 2 \\
\hline & & 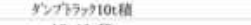 & $8.7 \mathrm{~kg} \cdot \mathrm{Ch}$ & wit:2 \\
\hline & & เร9)2ะ & $3.5 \mathrm{~kg} \cdot \mathrm{Ch}$ & 丵社2 \\
\hline & & 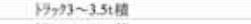 & $3.8 \mathrm{~kg}-\mathrm{Ch}$ & क्स: 2 \\
\hline & & 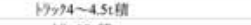 & $5 \mathrm{~kg}-\mathrm{Ch}$ & 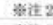 \\
\hline & & M-78th & $7.1 \mathrm{~kg}-\mathrm{Ch}$ & A A 注2 \\
\hline \multicolumn{5}{|c|}{ 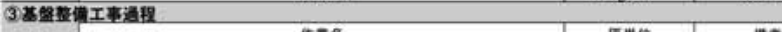 } \\
\hline & \multirow{15}{*}{ 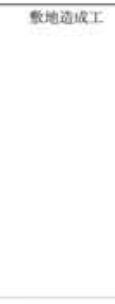 } & 假名 & 原戰但 & 此3 \\
\hline & & 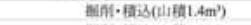 & $20 \mathrm{~kg}-\mathrm{C} 100 \mathrm{~m}$ & बił: \\
\hline & & 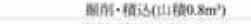 & $25.9 \mathrm{~kg}-\mathrm{C} 100 \mathrm{~m}^{3}$ & 䱜社: \\
\hline & & 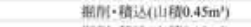 & $26 \mathrm{~kg}-\mathrm{C} 100 \mathrm{mi}$ & wa $: 3$ \\
\hline & & 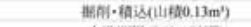 & $10 \mathrm{~kg}-\mathrm{C} 1 \mathrm{~lm}$ & क注: \\
\hline & & 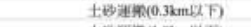 & $30 \mathrm{~kg} \cdot \mathrm{Cl} / 100 \mathrm{~m} \mathrm{~m}^{\prime}$ & \%证 4 \\
\hline & & 士Diased Otambit) & $40 \mathrm{~kg} \cdot \mathrm{C} 100 \mathrm{~m}^{\prime}$ & क传 4 \\
\hline & & 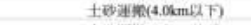 & $77 \mathrm{~kg}-\mathrm{C} / 100 \mathrm{~m}$ & 类流 4 \\
\hline & & 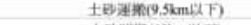 & $140 \mathrm{~kg}-\mathrm{C} 1100 \mathrm{~m}^{3}$ & 絭社 4 \\
\hline & & 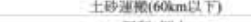 & $500 \mathrm{~kg} \cdot \mathrm{C} / 100 \mathrm{~m} \mathrm{~m}^{3}$ & 絭被 \\
\hline & & 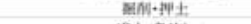 & $35.7 \mathrm{~kg}-\mathrm{C} / 100 \mathrm{~m}$ & w注 3 \\
\hline & & 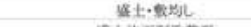 & $22.2 \mathrm{~kg}-\mathrm{C} 100 \mathrm{~m}$ & \%埕 3 \\
\hline & & 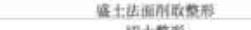 & $34 \mathrm{~kg}-\mathrm{C} 100 \mathrm{~m}$ & क注 3 \\
\hline & & 㭃土紫积 & $57.7 \mathrm{~kg}-\mathrm{C} 100 \mathrm{~m} \mathrm{~m}^{3}$ & *at 4 \\
\hline & & $x+6$ and & $160 \mathrm{~kg}-\mathrm{C} 100 \mathrm{~m}^{3}$ & 萦社 3 \\
\hline & \multirow{2}{*}{ 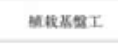 } & 费进期 & $0.9 \mathrm{~kg}-\mathrm{C} 100 \mathrm{~m}^{3}$ & \%社 3 \\
\hline & & 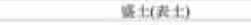 & $0.42 \mathrm{~kg}-0100 \mathrm{~m}^{3}$ & क社 3 \\
\hline & \multirow{4}{*}{ wer. } & 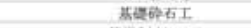 & $19 \mathrm{~kg}-\mathrm{Cl} 100 \mathrm{~mm}$ & \$洋 4 \\
\hline & & 基流耕 & $60 \mathrm{~kg}-\mathrm{C} 100 \mathrm{~m}$ & 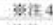 \\
\hline & & 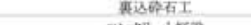 & $1230 \mathrm{~kg}-\mathrm{C} 100 \mathrm{~m}$ & 絭注 4 \\
\hline & & $3: 2 y=4 \pi$ & $11.9 \mathrm{~kg}-\mathrm{C} 10 \mathrm{~m}^{\prime}$ & s.it 4 \\
\hline (4) 棈数工 & 遇淎 & & & \\
\hline & 20 & fF原名 & 目戦位 & 粗3 \\
\hline & & 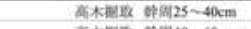 & $160 \mathrm{~kg}-\mathrm{Cl} 100 \mathrm{~s}$ & \%क. 4 \\
\hline & & 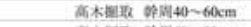 & $230 \mathrm{~kg}-\mathrm{C} / 100 \mathrm{t}$ & \%往 4 \\
\hline & & 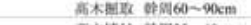 & $330 \mathrm{~kg}-\mathrm{Cl} 100 \mathrm{~s}$ & \%旅 4 \\
\hline & Fine.1. & 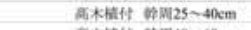 & $260 \mathrm{~kg}-\mathrm{Cl} 100 \mathrm{k}$ & \%注 4 \\
\hline & & 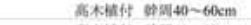 & $360 \mathrm{~kg}-\mathrm{Cl} 100 \mathrm{~K}$ & कit 4 \\
\hline & & 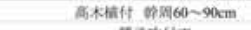 & $360 \mathrm{~kg}-\mathrm{Cl} 100 \mathrm{~A}$ & siz 4 \\
\hline & & A7*xtI & $4.1 \mathrm{~kg}-\mathrm{C} 1100 \mathrm{~m}$ & कat 4 \\
\hline & 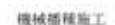 & 孚土够什工 & $17 \mathrm{~kg}-\mathrm{C} / 100 \mathrm{~m}$ & \%注 4 \\
\hline & 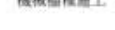 & 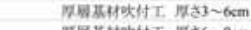 & $70 \mathrm{~kg}-\mathrm{C} 100 \mathrm{~m}$ & sia 4 \\
\hline & & DIf & $90 \mathrm{ks}-\mathrm{C} 100 \mathrm{~m}$ & 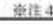 \\
\hline
\end{tabular}

\begin{tabular}{|c|c|c|c|c|}
\hline \multicolumn{5}{|c|}{ 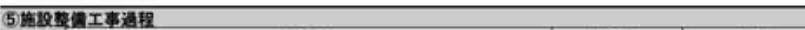 } \\
\hline 3) mexes & 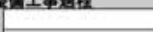 & 作暴名 & 原單儌 & 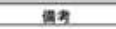 \\
\hline & & 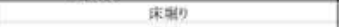 & $27 \mathrm{~kg}-\mathrm{C} 100 \mathrm{~m}$ & \\
\hline & 角零土工 & 明经 & $50 \mathrm{~kg}-\mathrm{Cl} 100 \mathrm{~m}^{2}$ & \\
\hline & & 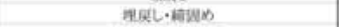 & $60 \mathrm{~kg}-\mathrm{Cl} 100 \mathrm{~m}$ & \\
\hline & 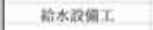 & 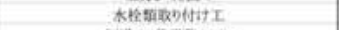 & $0.047 \mathrm{~kg}-\mathrm{C} / \mathrm{K}$ & \%住5 \\
\hline & & 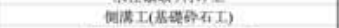 & $3.0 \mathrm{~kg} \cdot \mathrm{C} 100 \mathrm{~m}$ & жа \\
\hline & & 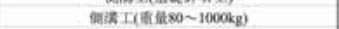 & $40 \mathrm{~kg}-\mathrm{Cl} 100 \mathrm{~m}$ & 莫注6 \\
\hline & & 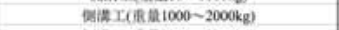 & $60 \mathrm{~kg} \cdot \mathrm{CH} 100 \mathrm{~m}$ & \%月6 \\
\hline & & 侄 & $80 \mathrm{~kg}-\mathrm{Cl} 10 \mathrm{~mm}$ & 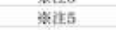 \\
\hline & & 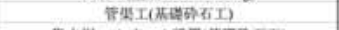 & $16 \mathrm{~kg}-0100 \mathrm{~m}$ & 类社6 \\
\hline & & 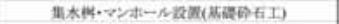 & $0.39 \mathrm{~kg}-\mathrm{C} 100 \mathrm{~m}$ & 样6 6 \\
\hline & & 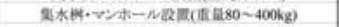 & $21 \mathrm{~kg}-\mathrm{C} 10 \mathrm{H}$ & 索注6 \\
\hline & Antagr & 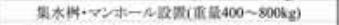 & $29 \mathrm{~kg}-\mathrm{C} 10 \mathrm{H}$ & \%許 6 \\
\hline & 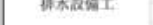 & 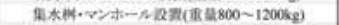 & $35 \mathrm{~kg}-\mathrm{Cl} 10 \mathrm{O}$ & 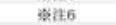 \\
\hline & & 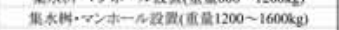 & $45 \mathrm{~kg}-\mathrm{C} 10 \mathrm{Ng}$ & 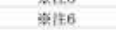 \\
\hline & & 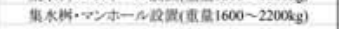 & $53 \mathrm{~kg}-\mathrm{C} 10 \mathrm{H}$ & 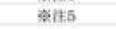 \\
\hline & & 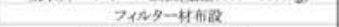 & $15 \mathrm{~kg}-\mathrm{C} J 100 \mathrm{~m}$ & \$作5 \\
\hline & & 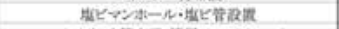 & 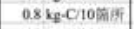 & \%क \\
\hline & & 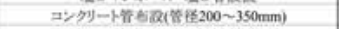 & $19 \mathrm{~kg}-\mathrm{ClOm}$ & 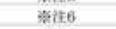 \\
\hline & & 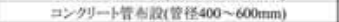 & $25 \mathrm{~kg}-\mathrm{ClOm}$ & \$注6 \\
\hline & & 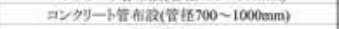 & $30 \mathrm{~kg}-\mathrm{Cl} 10 \mathrm{~m}$ & 絭注6 \\
\hline & 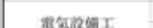 & 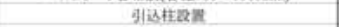 & $4.2 \mathrm{~kg}-\mathrm{CAE}$ & 䇣注7 \\
\hline & & 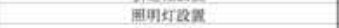 & $0.7 \mathrm{~kg}-\mathrm{CH}$ & 率社7 \\
\hline & & 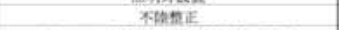 & $2 \mathrm{~kg}-1100 \mathrm{~m}^{2}$ & ж住3 \\
\hline & & 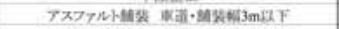 & $10 \mathrm{~kg}-\mathrm{Cl} 10 \mathrm{Om} \mathrm{m}^{2}$ & 萧拄3 \\
\hline & & 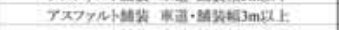 & $30 \mathrm{~kg}-\mathrm{C} 100 \mathrm{~m}^{2}$ & was \\
\hline & & 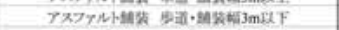 & $6.4 \mathrm{~kg}-\mathrm{C} 100 \mathrm{~m}^{2}$ & $\$ \neq 3$ \\
\hline & & 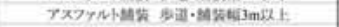 & $10 \mathrm{~kg}-\mathrm{Cl} 100 \mathrm{~m}^{2}$ & काE \\
\hline & 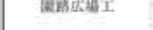 & 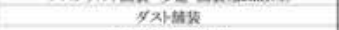 & $4 \mathrm{~kg}-\mathrm{C} 100 \mathrm{~m}^{7}$ & काँ 3 \\
\hline & & 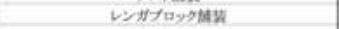 & $10 \mathrm{~kg}-\mathrm{Cl} 100 \mathrm{~m}$ & 类证了 \\
\hline & & 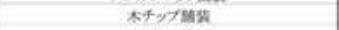 & $6 \mathrm{~kg} \cdot \mathrm{Cl} 100 \mathrm{~m}$ & 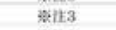 \\
\hline & & 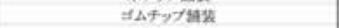 & $12 \mathrm{~kg}-\mathrm{C} 100 \mathrm{~m}$ & wit3 \\
\hline & & 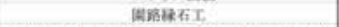 & $44 \mathrm{~kg}-\mathrm{Cl} 100 \mathrm{~mm}$ & (51.6), (118) \\
\hline & & 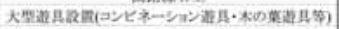 & $9 \mathrm{~kg}-\mathrm{ClK}$ & (⿻)丨子, (1E8) \\
\hline & 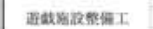 & 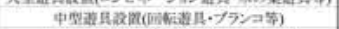 & $0.8 \mathrm{~kg}-\mathrm{C} / \mathrm{K}$ & 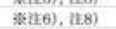 \\
\hline & & 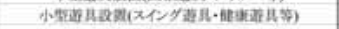 & $0.068 \mathrm{~kg}-\mathrm{C} / \mathrm{KK}$ & \$n.6), (158) \\
\hline & & 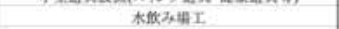 & $23 \mathrm{~kg}-\mathrm{C} / \mathrm{K}$ & 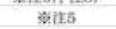 \\
\hline & & $27 I$ & $0.1 \mathrm{~kg}-\mathrm{Cl} / \mathrm{F}$ & $\$ 15.5$ \\
\hline & 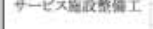 & $x \rightarrow \pi n I$ & $0.41 \mathrm{~kg}-\mathrm{C} / \mathrm{K}$ & 米注5 \\
\hline & & Mpatsis & $4 \mathrm{~kg}-\mathrm{C} / \mathrm{K}$ & क्wit.5 \\
\hline & 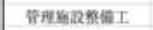 & 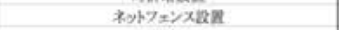 & $10 \mathrm{~kg}-\mathrm{C} 100 \mathrm{~m}$ & 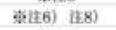 \\
\hline & 䖽めI & 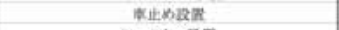 & $0020 \mathrm{~kg}-\mathrm{CH}$ & wits \\
\hline & 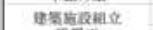 & $\forall \pm N タ-2 \times 10$ & $15 \mathrm{~kg} C \mathrm{CAK}$ & 慗被 \\
\hline & 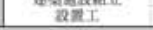 & 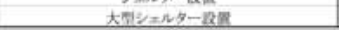 & $130 \mathrm{~kg}-\mathrm{CO}$ & watto \\
\hline 6)グラか & 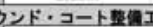 & & & \\
\hline & & 位暴名 & 面單位 & 狸皮 \\
\hline & grab:12:a-1 & 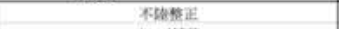 & $2 \mathrm{~kg}-\mathrm{Cl} 100 \mathrm{~m}^{2}$ & 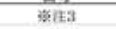 \\
\hline & (A12) & タ人俈商 & $39 \mathrm{~kg}-\mathrm{Cl} 100 \mathrm{~m}^{2}$ & 和住 3 \\
\hline & $y=\dot{y}: k \cdot=-1$ & 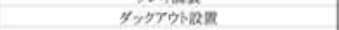 & $2 \mathrm{~kg}-\mathrm{CH} \mathrm{K}$ & \$事注3, \\
\hline & 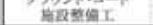 & ropzatan & $17 \mathrm{~kg}-\mathrm{CI} / \mathrm{s}$ & ब洋 3 \\
\hline 方通用. & 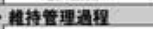 & & & \\
\hline & & Hexs & 原槿位 & an \\
\hline & & 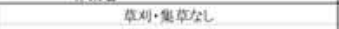 & $1.1 \mathrm{~kg} \cdot \mathrm{C} 1000 \mathrm{~m}$ & 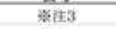 \\
\hline & 公国致的 & 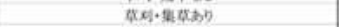 & $6.2 \mathrm{~kg}-\mathrm{Cl} 1000 \mathrm{~m}^{2}$ & wi被 \\
\hline & 党力洋A & 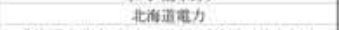 & $0.131 \mathrm{~kg}-\mathrm{Ckwh}$ & 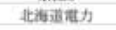 \\
\hline & 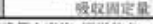 & 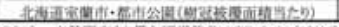 & $0.8+-C_{19} \cdot 4$ & \\
\hline 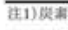 & 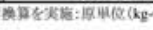 & 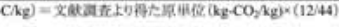 & क5 & 2. 1999 \\
\hline 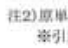 & 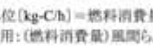 & 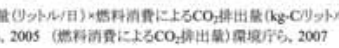 & & \\
\hline 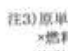 & 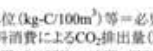 & 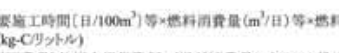 & 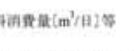 & \\
\hline & 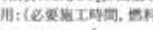 & 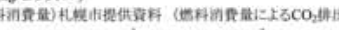 & 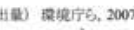 & \\
\hline 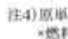 & 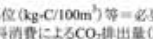 & 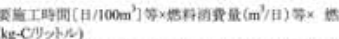 & 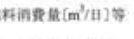 & \\
\hline & All: (L- & 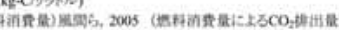 & 4) 920075,2007 & \\
\hline at5) 1050 & 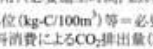 & 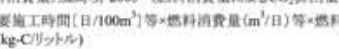 & 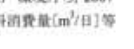 & \\
\hline & 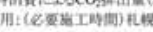 & 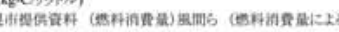 & 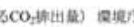 & S. 2007 \\
\hline 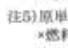 & 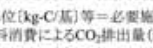 & 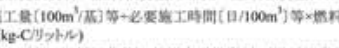 & 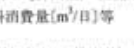 & \\
\hline & 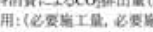 & 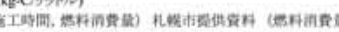 & A:s & 㙋佇5. 2007 \\
\hline 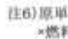 & 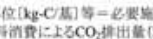 & 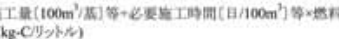 & 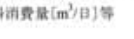 & \\
\hline w引l & 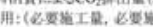 & 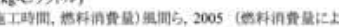 & 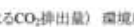 & 5,2007 \\
\hline (3) & 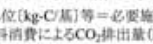 & 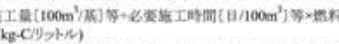 & 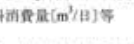 & \\
\hline & 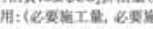 & 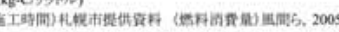 & 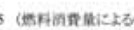 & \\
\hline
\end{tabular}




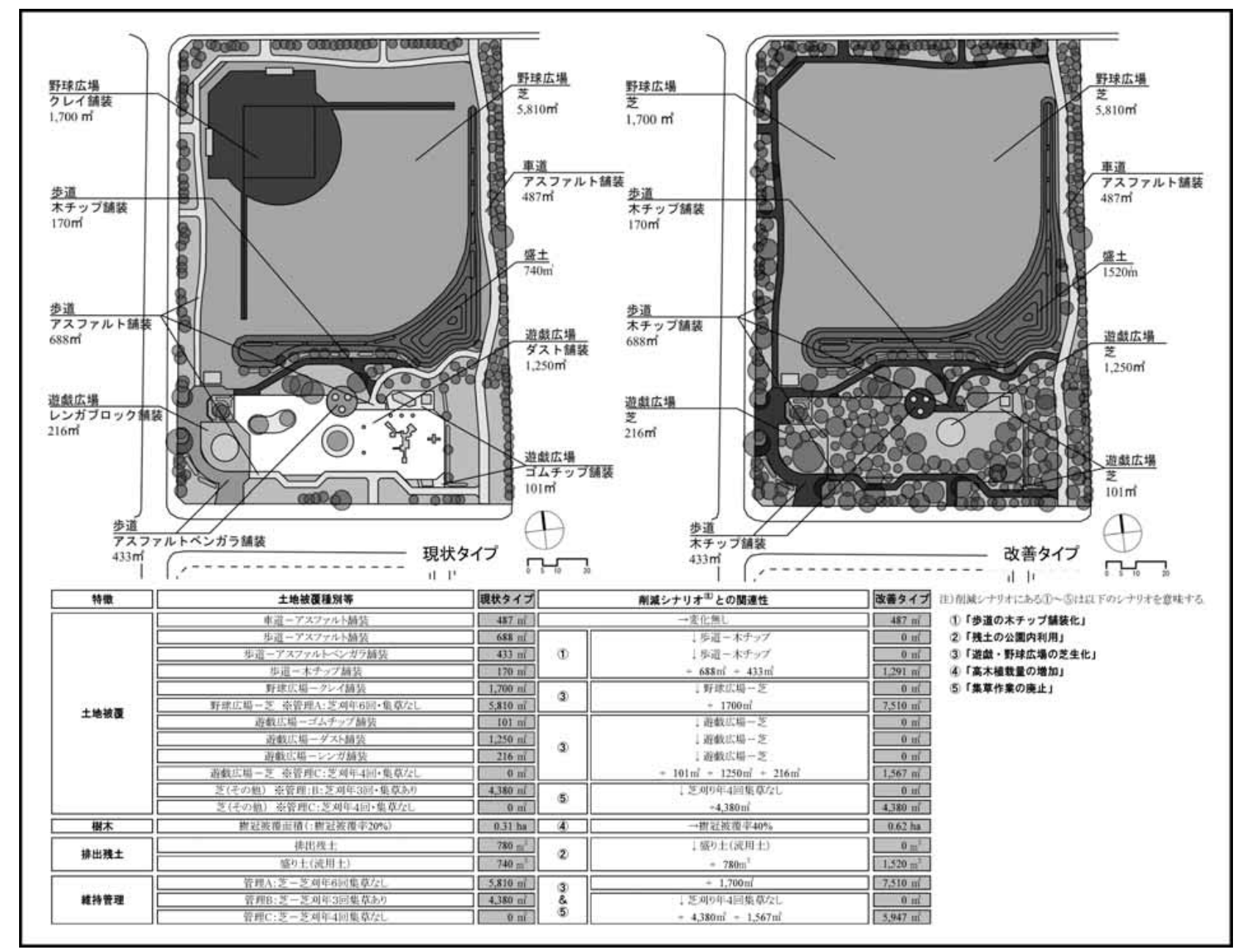

図-1 調査対象公園（現状タイプ及び改善タイプ）の状況

生土砂を公園内（盛土）で活用するシナリオ，(3「遊戯・野球広 場の芝生化」は，現状タイプにおいて一部ゴムチップ舗装やクレ イ舖装等の舗装であった遊戯広場・野球広場をすべて芝に変更し, さらに遊具については整備しないシナリオ, (4)「高木植栽量の増 加」は, 現状タイプにおいて樹冠被覆率 $20 \%$ であった高木植栽量 を2 倍（樹冠被覆率 40\%）にするシナリオ，(5)「集草作業の廃止」 は, 現状タイプにおいて「草刈年 3 回集草作業あり」を「芝刈年 4 回集草作業なし」に変更するシナリオである ${ }^{20)}$ 。

上記(1)〜(5)の「削減シナリオ」にもとづき整備された「改善夕 イプ」の評価対象公園の土地被覆 ・土地利用及び維持管理等の状 況は，図一 1 のようになる。

\section{(3) 評価対象公園における $\mathrm{LCCO}_{2}$ 評価}

「現状タイプ」及び「改善タイプ」各々の評価対象公園に対し $\mathrm{LCCO}_{2}$ 評価を実行した結果 ${ }^{21)}$ 〜3) 表一 2 及び表 -3 に示す。

(i ) 現状タイプに対する $\mathrm{LCCO}_{2}$ 評価

現状タイプに対する $\mathrm{LCCO}_{2}$ 評価を実行した結果, 現状タイプ の $\mathrm{LCCO}_{2}$ は $66,466 \mathrm{~kg}-\mathrm{C}$ となること, 各ライフサイクル過程の $\mathrm{CO}_{2}$ 排出量では, 運用・維持管理過程が最も大きく $(66,466 \mathrm{~kg}-\mathrm{C}: \mathrm{LC}$ $\mathrm{CO}_{2}$ の $\left.77.7 \%\right)$, 次に資材生産過程が大きく $(10,201 \mathrm{~kg}-\mathrm{C}: \mathrm{LC}$ $\mathrm{CO}_{2}$ の $\left.15.3 \%\right)$ なること, 現場での工事過程については $\mathrm{CO}_{2}$ 排出 量が比較的少ないこと, 特に植栽工事過程では作業がすべて人力 施工であったため, $\mathrm{CO}_{2}$ 排出量は $0 \mathrm{~kg}-\mathrm{C}$ となること等が把握された。

また, $\mathrm{CO}_{2}$ 排出量の大きかった運用・維持管理過程をみると, 樹木より $12,400 \mathrm{~kg}-\mathrm{C}$ の吸収固定が期待される一方, 照明灯の電力 消費による排出量が非常に大きい $(58,072 \mathrm{~kg}-\mathrm{C})$ ことが把握された。 （ii）評価対象公園（改善タイプ）に対する $\mathrm{LCCO}_{2}$ 評価

改善タイプに対する $\mathrm{LCCO}_{2}$ 評価を実行した結果, 改善タイプ の $\mathrm{LCCO}_{2}$ は 46,062t-C となること,「現状タイプ」の $\mathrm{LCCO}_{2}$ と比 較すると, $-20,404 \mathrm{~kg}-\mathrm{C}(-30.7 \%)$ の削減となること, 各削減シ ナリオの削減効果をみると, (4)「高木植栽量の増加」が-12,400 $\mathrm{kg}-\mathrm{C}(-18.7 \%)$ と削減量が大きく, 次いで，(5)「集草作業の廃 止」 $(-4,222 \mathrm{~kg}-\mathrm{C}(-6.4 \%))$, (1)「歩道の木チップ化」 $((-2,997 \mathrm{~kg}-$ C $(4.5 \%))$, (2)「残土の公園内活用」 $(-1,020 \mathrm{~kg}-\mathrm{C}(-1.5 \%)$ と なること，「(3)遊戯・野球広場の芝生化」は，資材生産過程や現場 の工事過程に関わる 4 過程で $\mathrm{CO}_{2}$ 排出が削減されたが, 草刈作 業量の増加に伴う維持管理過程の $\mathrm{CO}_{2}$ 排出量の増加により +235 $\mathrm{kg}-\mathrm{C}(+0.4 \%)$ の $\mathrm{CO}_{2}$ の排出増加となること等が把握された。

\section{4. おわりに}

ここまで得られた結果を整理しつつ, 都市公園あるいは都市緑 地における $\mathrm{LCCO}_{2}$ 評価の可能性等について，以下に検討する。

まず，本研究では，前述したとおり都市公園の整備費用の「積 算」との連携を意識した $\mathrm{LCCO}_{2}$ 評価手法を構築した。また，構 築した $\mathrm{LCCO}_{2}$ 評価手法は, 実際の都市公園に適用可能であるこ とが把握された。これらのことにより，これまで確認されてこな かった都市公園等の都市緑地における $\mathrm{LCCO}_{2}$ 評価の「技術面」 からの導入可能性について確認できたと考えられる。また, 本研 究で構築した $\mathrm{LCCO}_{2}$ 評価手法は, 「積算」との連携を意識して いることから，従来の「積算」作業之同時進行的に $\mathrm{LCCO}_{2}$ 評価 が可能となるようなシステム構築の可能性も示唆された。 
表－2 評価対象公園における（現状タイプ及び削減タイプ）に対する $\mathrm{LCCO}_{2}$ 評価(1)

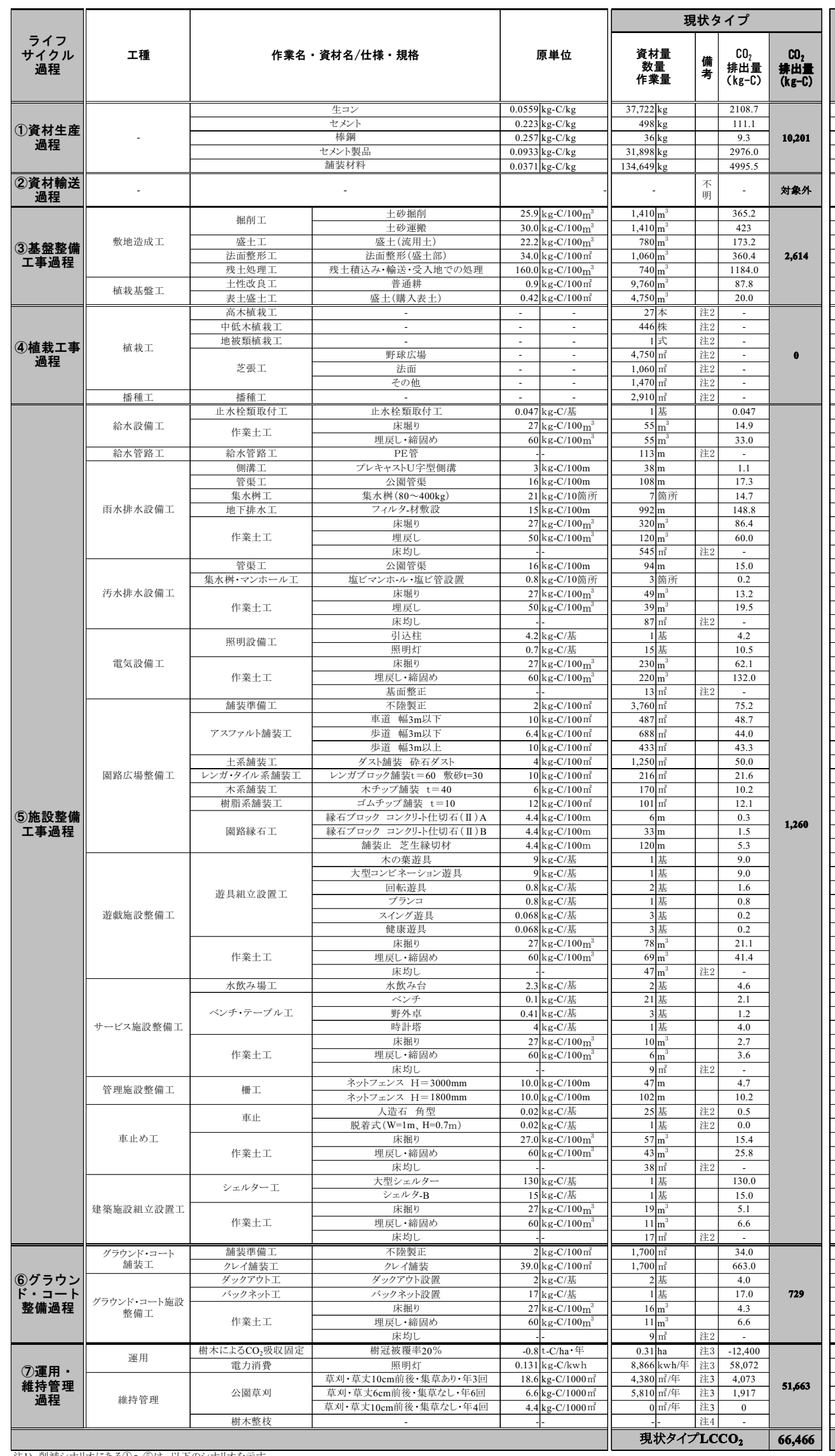

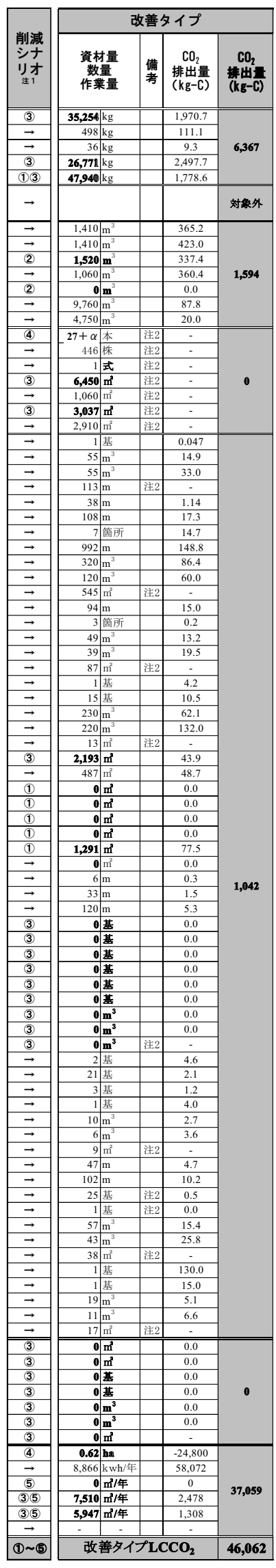

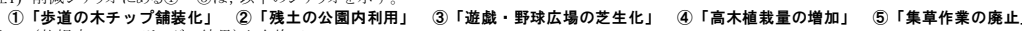

注3) 原単位が年間当たりとなっているため本研究のライフサイクルの評価期間開設後 50 年に対応させるため, 50 を乘している

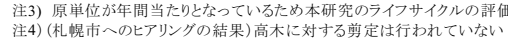


表－3＼cjkstart評価対象公園における（現状タイプ及び削減タイプ）に対する $\mathrm{LCCO}_{2}$ 評価(2)

\begin{tabular}{|c|c|c|c|c|c|c|c|c|c|c|c|c|c|c|c|c|}
\hline \multirow{5}{*}{ ライフサイクル迹期 } & \multirow{5}{*}{ 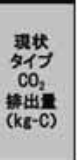 } & \multicolumn{14}{|c|}{ 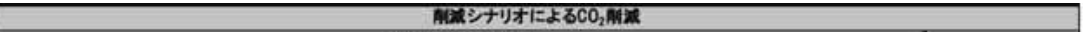 } & \multirow{5}{*}{ 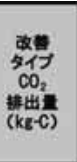 } \\
\hline & & \multicolumn{12}{|c|}{ 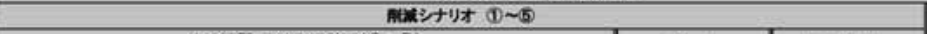 } & \multirow{3}{*}{\multicolumn{2}{|c|}{ 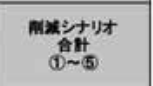 }} & \\
\hline & & \multicolumn{8}{|c|}{ 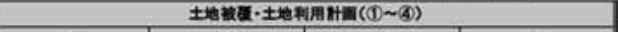 } & \multirow{2}{*}{\multicolumn{2}{|c|}{ (1) }} & \multirow{2}{*}{\multicolumn{2}{|c|}{ ก: }} & & & \\
\hline & & \multicolumn{2}{|c|}{ (1) } & \multicolumn{2}{|c|}{ (2) } & \multicolumn{2}{|c|}{3} & \multicolumn{2}{|c|}{ (4) } & & & & & & & \\
\hline & & $\operatorname{mox}_{(k \leq-C)}$ & $\operatorname{mix} *$ & $\operatorname{mix}_{0<-c)}^{\max }$ & $\max$ & $\operatorname{maxh}_{(k=-C)}$ & $\max =$ & $\underset{\substack{\operatorname{mux} \\
(x \in-C)}}{ }$ & $\max =$ & 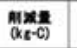 & $\operatorname{mox}=$ & 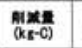 & $\operatorname{mix}=$ & $\operatorname{mix}_{\alpha \in t-C)}$ & $\operatorname{mix}=$ & \\
\hline 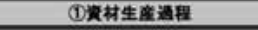 & 10,201 & $-2,977$ & $+.5 \%$ & 0 & $0.0 \%$ & $\$ 6$ & $-1.3 \%$ & 0 & $0.00 \%$ & $-3,003$ & $5.8 \%[$ & 0 & 0.006 & $-3,003$ & $8.85 \%$ & 6,367 \\
\hline 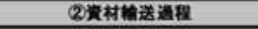 & 차요아 & & & & & & & + & & & & & & & & 然繁外 \\
\hline 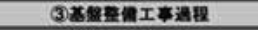 & 2,614 & 0 & $0.0 \%$ & $-1,020$ & $-4.5 \%$ & 0 & 0.006 & 0 & 0.055 & $-1,2,20$ & $-1.5 \%$ & 0 & 0.05 & $-1,020$ & $-1.5 \%$ & 1,594 \\
\hline (4)推暽工事通理 & 0 & 0 & $0.0 \%$ & 0 & $0.0 \%$ & 0 & $0.0 \mathrm{~N}$ & 0 & $0.0 \%[$ & - & 0.0056 & 0 & $0.0 \%$ & 0 & $0.0 \%$ & 0 \\
\hline 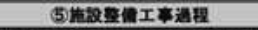 & 1,260 & 20 & $0.0 \%$ & of & 0.05 & -198 & $0.3 \%$ & 0 & $0.0 \%$ & 418 & $0.3 \times$ & $\circ$ & $0.0 \%$ & 218 & $-0.3 \%$ & 1,042 \\
\hline 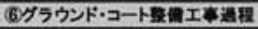 & 729 & 0 & $0.0 \%$ & 0 & 0.05 & .729 & $-1.1 \%$ & 0 & 0.05 & -729 & $-1.1 \%$ & 0 & $0.0 \%$ & .729 & $-1.1 \%$ & 0 \\
\hline 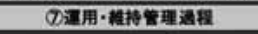 & 51,663 & 0 & $0.0 \%$ & 0 & $0.0 \%$ & 2,018 & $3.0 \%$ & $-12,400$ & $-18.7 \%$ & $-10,382$ & $-15.6 \%$ & $-4,222$ & $-6.4 \%$ & $-14,604$ & $0.0 \%$ & 37,059 \\
\hline 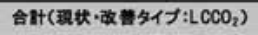 & 66,466 & $-2,997$ & $-4.5 \%$ & $-1,020$ & $-1.5 \%$ & 235 & $0.4 \%$ & $-12,400$ & $-18,7 \%$ & $-16,182$ & $-24.3 \%$ & $-4,222$ & $-6.4 \%$ & $-20,404$ & $30.7 \%$ & 46,062 \\
\hline
\end{tabular}

次に, 評価対象公園 (一般的な近隣公園) に対する $\mathrm{LCCO}_{2}$ 評 価の結果，現状タイプでは，「約 $66.5 \mathrm{t}-\mathrm{C} 」$ の $\mathrm{CO}_{2}$ の「排出」となっ ていることが把握され，一般的な利用型の都市公園整備は，ライフ サイクルの観点からみると $\mathrm{CO}_{2}$ の排出源となっている可能性が高 いことが確認された。このことより, 今後, 地球温暖化防止に向 け, 都市公園等の整備においては, $\mathrm{CO}_{2}$ の「吸収源」という側面 のみならず， $\mathrm{CO}_{2}$ の「排出」の側面についても考慮する必要性が 示唆された。そのような「排出」の側面も含めた整備計画等の検 討にあたっては，「排出」の側面も含めた定量的な評価である $\mathrm{LCCO}_{2}$ 評価が必要不可欠といえ, 都市公園等に対する $\mathrm{LCCO}_{2}$ 評 価手法を様々な観点から検討する必要性が改めて確認された。

さらに, 各種の $\mathrm{CO}_{2}$ 排出の削減シナリオを踏まえた「改善夕 イプ」に対しても $\mathrm{LCCO}_{2}$ 評価を実行した結果, 各種の $\mathrm{CO}_{2}$ 削減 シナリオによる $\mathrm{CO}_{2}$ 削減効果を定量的に把握することが可能で あった。地球温暖化防止を考慮した都市公園等の整備を検討する 際, $\mathrm{CO}_{2}$ の排出削減のみならず, その他機能やコス卜面を考慮し た複数のシナリオ, 整備計画を検討し, 選択する必要があるが, 本研究で構築した $\mathrm{LCCO}_{2}$ 評価手法を用いれば各シナリオの $\mathrm{CO}_{2}$ 排出量, $\mathrm{LCCO}_{2}$ を定量的に評価することが可能であり, より明 確に $\mathrm{CO}_{2}$ の排出削減とその他考慮すべき点とのバランスを考え シナリオの選択を行うことが出来る。また, 繰り返しになるが本 研究で構築した $\mathrm{LCCO}_{2}$ 評価手法は, 「積算」との連携を意識し ていることから，特に $\mathrm{CO}_{2}$ の排出削減と「コスト面」とのバラ ンスについての検討がより容易なシステム構築も可能と考える。

2050 年には $\mathrm{CO}_{2}$ の排出量の半減が求められる中, 都市構造の あり方についても抜本的な改革が必要 ${ }^{24)}$ であり「低炭素都市の構 築」等が期待されている ${ }^{24)}$ 。このような状況の中, 都市公園等の 都市緑地においても $\mathrm{LCCO}_{2}$ の概念を導入することで，これまで 同じ評価軸で捉えることが困難だった建築, 土木空間と都市緑地 を $\mathrm{CO}_{2}$ という評価軸で一元的に捉えることが可能となり, 低炭 素型の土地利用として都市緑地は明確に位置づけられると同時に, 改革の方向性として「都市緑地を基軸とした低炭素都市の構築」 等の検討も可能となると考えられる。例えば, 都市全体に LCC $\mathrm{O}_{2}$ 評価の概念を導入することで, 湯沢 ${ }^{24)}$ も指摘するような, 近 年の国際, 国内において着目される「 $\mathrm{CO}_{2}$ 排出権取引（カーボン オフセット)」等の仕組みを視野に入れた都市緑地あるいは都市 構造のあり方に関わる各種の検討も可能になると考えられる。

今後の課題として, 本研究で把握困難だった原単位や作業量等 に関する対応策を検討すること, 緑のリサイクルやバイオマスエ ネルギー等についても考慮すること, 前述した低炭素都市構築を 視野に入れ，緑地・建築・土木空間を含む最小単位空間「街区」 を対象とした $\mathrm{LCCO}_{2}$ 評価を検討すること等が挙げられる。

謝辞 : 本研究を遂行するにあたり, 札幌市環境局みどりの推進部 黒澤佑介氏には資料提供等の御協力を頂いた。記して感謝の意を 表します。
補注及び引用文献

1) 地球温暖化防止に向けた吸収源対策としての「都市緑化」に関わる IPCC, COP 等における国際社会の議論については, 半田ら $(2005)^{7)}$, 加藤 $(2005)^{25}$ 等が詳 しい。それに伴う近年の我が国の動向, 例えば, 京都議定書目標達成計画（2008 年 3 月の改訂の内容等) については, 小野 $(2008)^{26)}$ 等が詳しい。

2 ) 本研究で用いた「都市緑地」は, 都市公園等の 1 種別としての狭義の「都市緑地」 ではなく，都市における各種緑地（都市公園，街路樹，及び住宅等の民有地の緑， 他）を包括的に捉える広義の「都市緑地」を意味する。

3) Koji ICHIMURA and Daiki YAEGASHI (2007) : Study of Estimating the Amount of Carbon Storage and Sequestration in Urban Green Spaces Based on Tree Crown Cover Area in Hokkaido: Journal of Environmental Information Science, 35(5), 29-36

4) 市村恒士（2006）：樹冠被覆面積にもとづく都市緑地の二酸化炭素固定量の推定 に関する研究 : ランドスケープ研究 69(5), 613-616

5 ) 市村 恒士・黑澤 和隆 (2005) : 都市林の二酸化炭素固定効果に関する研究-北海 道帯広市「帯広の森」を事例として：日本建築学会環境系論文集 $597,81-87$

6 ）市村 恒士・岡田 孝幸・柳井 重人・丸田 頼一 (1999) : 都市公園における樹木 の二酸化炭素固定効果に関する研究 : 日本都市計画学会学術研究論文集 $34,1-6$

7) 半田真理子・手代木 純 (2005) : 地球温暖化防止に資する都市緑地の評価：都市 緑化技術 $56,81-87$

8 ）豊田 幸夫（2001）：環境配慮設計とライフサイクル評価：都市緑化技術 41 , 27-30

9 ）酒井 寛二・漆崎 昇・相賀 洋・下山 真人（1996）：建物のライフサイクル二酸 化炭素発生量とその抑制方策に関する研究：日本建築学会計画系論文集 484, 105112

10）岩田 衛・堂野前 等・久松雄治（2000）：建築鉄骨構造のライフサイクルにおけ る環境負荷削減のシナリオとその評価：日本建築学会構造系論文集 533, 167-173

11）日本建築学会（1999）：建物の LCA 指針 ～温暖化・資源消費・廃棄物対策の ための評価ツール：日本建築学会, $178 \mathrm{pp}$

12）風間 伸造（2005）：造園修景積算マニュアル：財団法人建設物価調查会, $514 \mathrm{pp}$

13）竹林 芳久・岡 建雄・紺矢 哲夫 (1992) : 産業連関表による建築物の評価 その 2 事務所建築の建設による環境への影響：日本建築学会計画系論文報告集 431 , $31-32$

14）鈴木 道哉・岡 建雄・岡田 圭史（1994）：産業連関表による建築物の評価その 3 住宅建設によるエネルギー消費量 : 二酸化炭素排出量, 日本建築学会計画系論 文集 463, 75-82

15）鈴木 道哉・岡 建雄・岡田 圭史・矢野 謙禎（1995）：産業連関表による建築物 の評価 その 4 事務所ビルの建設・運用に関わるエネルギー消費量, 二酸化炭 素排出量：日本建築学会計画系論文集 476,37-43

16）文献等で得られた原単位が $\mathrm{CO}_{2}$ 換算重量の場合, $\mathrm{CO}_{2}$ を構成する $\mathrm{C} と \mathrm{CO}_{2}$ の質量 比 $\left(\mathrm{C}: \mathrm{CO}_{2}=12: 44\right)$ を用いて炭素換算を行った

17）環境省（1992）：二酸化炭素排出量調查報告書

18）施設整備工事過程の園路縁石工，大型遊具設置，中型遊具設置，小型遊具設置， ネットフェンス設置については, 各規格の原単位の值に大きな差がなかったため, $\mathrm{LCCO}_{2}$ 評価の簡略化のために各規格の平均值を原単位とした。

19) 北海道電力 $(2007)$ : ほくでんサスティナビリティレポート 2007 : 北海道電力, $70 \mathrm{pp}$

20）札幌市役所へのヒアリングによって,草刈年 3 回以下では集草作業を要し，年 4 回 以上では集草を要しないことが把握された。また，近年の維持管理予算削減によっ て,草刈りは年 4 回実施であったが年 3 回に減少し,その結果, 集草作業が発生して いることも把握された。

21）「資材生産過程」においては，植物生産による $\mathrm{CO}_{2}$ 排出・吸収について，原単位 が得られなかったこと等から評価対象外とした。また，原単位と異なる単位系 （例えば，原単位は重量べース $(\mathrm{g}-\mathrm{C} / \mathrm{kg})$ に関わらず，積算資料では長さべース (例えば，ポリエチレン管「 $\phi 50,6.6 \mathrm{~m} 」$ 等)）については, 重量に変換出来なかっ たこと等から評価対象外とした。なお，これらを評価対象外したことによる LCC $\mathrm{O}_{2}$ 評価への影響は，対象外とした資材量が少ないことから比較的小さいものと推 察される。

22）「資材輸送過程」に扔いては，原単位は得られたものの，明確な輸送資材重量及び 輸送距離が得られなかったため評価対象外とした。なおここれらを評価対象外し たことによる $\mathrm{LCCO}_{2}$ 評価への影響は，原単位も大きいことから比較的大きいもの と推察される。

23）造成予定地に既存施設がある場合に実施される撤去工事や，整備後の樹木の枯死 や市民のニーズ変化等による再整備等については，評価対象外としている。また， トイレについては公園整備とは別途の工事で計上されるものであり評価対象外之 した。

24）湯沢 将憲（2008）：温室効果ガス吸収源対策としての都市緑地について：都市緑 化技術 $69, \quad 10-13$

25）加藤 順子（2005）：地球温暖化防止と都市緑化等の推進：都市緑化技術 56, 15

26）小野 貴子（2008）：温室効果ガス排出・吸収量の算定の仕組みと日本の取り組み に扮ける都市緑地：都市緑化技術 69, 6-9 